\title{
Epidemiological profile of the notified cases of leprosy in the state of Paraná-Brasil, 2007-20I5
}

\begin{abstract}
Objective: To analyze the epidemiological profile of the reported cases of leprosy in the State of Paraná in the last nine years.

Methods: A retrospective descriptive study was carried out through the SINAN database from January 2007 to December 2015.

Results: The sample is composed of a historical series of 11056 cases reported in Paraná between 2007 and 2015, with predominance of incomplete elementary male white male adult with multibacillary operational forms, and virchowian and dimorphic clinical classification. There was a decrease in the notification in this period, but the serious and debilitating conditions of the disease still prevail. Discussion: Still with the decrease, Brazil still has not been able to fulfill one of the Millennium Development Goals of registering only 1 case of leprosy per 10,000 inhabitants, and only in Paraná in 9 years were notified 9582 new cases.
\end{abstract}

Conclusion: There is a need for more investments for better awareness, surveillance, control and elimination of the disease.

Keywords: leprosy, mycobacteriosis, mycobacterium leprae, epidemiology, sneezing, coughing, speech, anamnesis, general physical examination, neurological evaluation
Volume 3 Issue 5 - 2019

\author{
Isabella Gil,' Lais Nicole Gonçalves Panizzi,' \\ Kátia Sheylla Malta Purim² \\ 'Collection and analysis of data,Active search of literature on \\ the subject of Epidermology, Brazil \\ ${ }^{2}$ Doctor of Medicine, Universidade Positivo, Brazil
}

\begin{abstract}
Correspondence: Isabella Gil,Active search of literature on the subject of Epidermology, Collection and analysis of data, Brazil, Rua Rosa Kaint Nadolny, Campo Comprido, Curitiba/PR - Brazil, Postal Code: 8I200-525, Tel +55 (4I) 999987600 Email bela_gil@hotmail.com
\end{abstract}

Received: October 16, 2019 | Published: October 30, 2019
Abbreviations: WHO, world health organization; $\mathrm{MOH}$, ministry of health

\section{Introduction}

Due to its importance and magnitude, leprosy is a compulsory communication disease for all health professionals according to the Information System for Notifiable Diseases (SINAN). ${ }^{1}$ This disease is contagious, chronic and curable, but it has a potential for physical, emotional and occupational limitations when not diagnosed and treated correctly. ${ }^{2}$ Researching the state of the disease cases can add new knowledge to promote better prevention, care and rehabilitation in health. Leprosy is a mycobacteriosis caused by Mycobacterium leprae (M. leprae), called Hansen's bacillus, capable of affecting skin, peripheral nerves and other systems in a localized or systemic way, depending on the immunogenic characteristics of the host. ${ }^{3}$ Transmission occurs through bacilli expelled by sneezing, coughing, speech and breathing of the infected individual, according to prolonged and frequent contact. Its diagnosis is made through anamnesis, general physical examination, dermatological and neurological evaluation of the thermal, tactile and tactile sensibility and palpation of peripheral nerves, complemented by smear microscopy of the patient who presents lesions of the skin with a sensitivity disorder. ${ }^{4-5}$ The disease is classified clinically in four forms: indeterminate, tuberculoid, borderline or dimorphic, and virchowian. ${ }^{4-6}$

In the Undetermined form, the initial lesion may or may not be visible, with a hypoesthetic area, and one or more hypopigmented and drier patches may appear that surround the skin, with slow development, involution or evolution with spontaneous cure. ${ }^{4,7}$ The Tuberculoid form may present as a macula (hypochromic or erythematous lesion delimited by micro-papules) or plaque (erythematous or coppery lesion, with well defined limits), only or in a small number, and leads to damage in neural branches, evolving to hypoesthesia and anesthesia, dry skin with decreased or absent hairs. ${ }^{4}$ In the Dimorph form, erythematous maculae are observed in light or hypochromic skin on dark skin, with the presence of papules, tubers, nodules and plaques; approaching both the Tuberculoid and Virchowian forms. In the tuberculoid pole the lesions are more delimited and of dry surface; in the Virchowian pole the lesions are more numerous, bright and with lower definition of limits. ${ }^{7}$ The Virchowian form is insidious and begins with ill-defined, discreetly hypochromic or erythematous macules, evolving with increased erythema and infiltration, papules, nodules and tubers. It affects multiple nerve trunks, causing sensory and motor loss, muscular atrophy, paralysis and deformities, and even other organs and systems, being the most severe and incapacitating.

The operational classification of leprosy is based on the number of cutaneous lesions and smear microscopy for the purpose of polychemotherapy treatment. When patients present up to 5 skin lesions, they are considered paucibacillary, and when they present more than five, they are multibacillary. ${ }^{4,8}$ Positive smear microscopy classifies the case as multibacillary. However, the negative result does not exclude the diagnosis of the disease, because in the paucibacillary it is usually negative. This examination is fundamental in case of doubt in the operational classification for the institution of multi-chemotherapy, for differential diagnosis with other dermatoneurological diseases and cases suspected of relapse. ${ }^{4}$ Currently, epidemiological studies on leprosy in Paraná are scarce, and for a better sizing of this condition it is necessary to collect data and a more reliable analysis, so that health authorities, society, educational institutions, multiprofessional teams, patients and their families can improve their coping and eradication. 


\section{Goals}

To analyze the epidemiological profile of the reported cases of leprosy in the State of Paraná-Brazil between 2007-2015, knowing the temporal incidence of the cases, their distribution and comparison of variables.

\section{Methodology}

Epidemiological study of a historical series of reported cases of leprosy in the state of Paraná between January 2007 and December 2015, descriptive and retrospective. The electronic data collection was done with the assistance of the State Coordination of the Leprosy Control Program of the State Health Department of Paraná (SESA/ PR), using standardized and individualized files from the SINAN database (Notification Disease Information System). As inclusion criterion were added the compulsory notification sheets for leprosy, whose fields of data proposed for analysis were completed. The following variables were analyzed: age, sex, race, socioeconomic profile, municipality of residence of the patient, number of cutaneous lesions, clinical form of the disease, operational classification, number of nerves affected, degree of physical incapacity and initial therapeutic scheme. Cases were also evaluated for their temporal incidence. The project was previously submitted and approved by the institutional ethics committee (CEP-UP 1,585,046) and by SESA/PR, obeying Resolution of the National Health Council CNS no. 466/2012. Data were analyzed from descriptive statistics.

\section{Results}

In the period from 2007 to 2015, 11,056 cases of leprosy in the state of Paraná were enrolled in the SINAN, with 4.612 cases belonging to the female sex (41.7\%) and 6.444 male cases $(58.3 \%)$. New cases of the disease totaled $86.7 \%$, with 9.582 patients. There were also 645 relapses, 443 transfers and 383 other ways of entering the database. In the detection of new cases, there was a predominance of referrals, with $54.4 \%$ of the cases; spontaneous demand came in second, with $35.8 \%$. Regarding the prevalence of the sexes, only in 2009 were female cases (631 cases, $45.1 \%$ ), while the incidence and overall prevalence of notification were in the male cases, the highest in 2015 (596 cases, 63 cases, 4\%). The average age of the diagnosis was 50 years, but 46 cases were excluded without information on the date of birth. Correlated with the clinical form, the average age of the cases in the indeterminate form was 44,4 years; tuberculosis was 48,2 years; in the dimorphous form was 51,4 years; and in Virchowian it was 51,3 years. In the tuberculoid form, the minimum age of 2 years was identified, while the maximum age of 98,5 was found in the Virchowian form (Table 1). The analysis showed the prevalence of clinical forms: Virchowian (4.186 cases, 38,3\%); Dimorph (3.424 cases, 31,3\%); Tuberculoid (1.662 cases, 15,2\%); Indeterminate $(1.282$ cases, $11,7 \%)$. There were also unclassified cases ( 386 cases, $3,5 \%)$. As for gender, there was predominance of the Virchowian form between men $(47,3 \%)$ and the dimorphic form $(33,1 \%)$ in women.

Table I Age of patients with leprosy in diagnosis and identified clinical form $(\mathrm{N}=\mid \mathrm{I} .056)$

\begin{tabular}{lllllll}
\hline Clinical Form & \multicolumn{2}{l}{ Age at diagnosis (years) } & & & \\
\hline & Number of patients & Average & Median & Minimum & Maximum & Standard deviation \\
\hline Undetermined & 1278 & 44,4 & 45,0 & 4,8 & 91,1 & 16,8 \\
Tuberculoid & 1653 & 48,2 & 49,4 & 2,2 & 87,8 & 16,6 \\
Dimorphic & 3413 & 51,4 & 52,4 & 4,5 & 95,2 & 15,6 \\
Virchowian & 4169 & 51,3 & 51,9 & 5,7 & 98,5 & 15,7 \\
\hline
\end{tabular}

Source:The Author

The correlation between the number of cutaneous lesions and the clinical forms showed a prevalence of the tuberculoid form between a total of a maximum of 4 lesions and of the dimorph between 5 and 9 lesions. Variations greater or equal to 15 lesions were found between the virchowian and dimorphic forms, presenting high prevalences. As to the number of nerves affected, the indeterminate form was superior in cases where there was no neural lesion $(79,9 \%)$, whereas the Virchowian form was more prevalent between 1 and 6 affected nerves (49\%), and the dimorph between 7 affected or more nerves $(2,5 \%)$, with $\mathrm{p}$ value $<0.001$ (Chi-square test). The evolution of the disease was analyzed in the discharge of the patient, correlating the clinical form in the diagnosis and the physical incapacity of the same, being able to improve or worsen. There was improvement in $68,4 \%$ of the patients who presented the indeterminate form; in $67,01 \%$ of patients with the tuberculoid form; in $62 \%$ of patients with the dimorphic form; and in $65,5 \%$ of patients with the Virchowian form. Assessing the physical disability of the total number of patients, the dimorphic form had a higher prevalence of worsening compared to the other clinical forms $(37,9 \%)$.

\section{Discussion}

According to the World Health Organization (WHO), every person who has one or more criteria (skin lesions with altered sensitivity, thickening of one or more peripheral nerves and altered sensitivity, and smear microscopy positive for Hansen's bacillus), with or without epidemiological history and requiring specific chemotherapy treatment, presents leprosy. ${ }^{4-8}$ According to data from the Ministry of Health $(\mathrm{MOH})$, because it is a compulsory notification disease, the goal of disease elimination is based on the indicator of detection of new cases1,9. In Paraná, there were 9.582 new cases in 9 years, with an average of 1.064,6 cases per year. During this period there was a decrease in notifications, with a peak in 2007 (1.534 cases, $13,9 \%$ ) and the decrease in 2014 (923 cases, 8,3\%). This decrease was also observed by the Interagency Network for Health Information (RIPSA), which revealed a national fall in the prevalence of leprosy between 1990 and 2006, with an impact in 2004 and 2005, which presented 3,2 and 3,1 cases per 10.000 inhabitants, respectively. ${ }^{10}$ In 2003 the prevalence was 4,52 per 10.000 inhabitants, and the Ministry 
of Health ${ }^{11}$ reported that in 2013 it was 1,42 per 10.000 inhabitants, revealing a remarkable fall of $68 \%$. In 2010, Brazil had 1,56 cases of leprosy for every 10.000 inhabitants, with 29.761 cases being treated. In that same year, 34.894 new cases of leprosy were detected, corresponding to a general detection coefficient of $18,2 / 100.000$ inhabitants, showing a decrease in the detection coefficient from 2001 to 2010 .

Even at a declining rate, Brazil was not able to comply with one of the United Nations Millennium Development Goals, to eliminate leprosy as a public health problem by the end of 2015 (with only 1 case per 10.000 population), which a country in the world that has not been able to eliminate the disease and which concentrates more new cases of it every year., ${ }^{9}$ According to the classification of neglected and other diseases related to poverty, leprosy is one of the set of diseases that tend to coexist in areas where the population presents precarious conditions of life $^{13}$. Even though they are responsible for an important morbidity and mortality, the burden of neglected diseases is underestimated in Brazil. ${ }^{11}$ In 2011, the Secretariat of Health Surveillance created the General Coordination of Leprosy and Eliminating Diseases to strengthen the response to a group of diseases whose results from the national programs were considered insufficient and incompatible with the capacity of the Unified Health System to solve the health problems of the population, including leprosy, schistosomiasis, lymphatic filariasis, geohelminthiases, onchocerciasis and trachoma. ${ }^{13}$

The proportion of people affected remains high among the poorest and most marginalized populations in Brazil, corroborating the fact that individuals with greater social vulnerability are at high risk of becoming ill. Since the provision of health services to meet the spontaneous demand of these endemic cases has not been enough to reduce disease burden or elimination, it is aimed at the early detection of cases and the treatment of more individuals to impact on the environmental circulation of etiological agents and reduce the appearance of new cases. ${ }^{10-13}$ Preliminary data released by the
Ministry of Health indicate that the general detection rate of leprosy was 12,14 per 100.000 inhabitants in 2014, with 24.612 new cases. This demonstrates an increase in prevalence, which comes in shock with the trend of declining notifications. ${ }^{13}$ Miranzi et al. ${ }^{14}$ in the study of the epidemiological profile of leprosy in a brazilian city between 2000 and 2006 , obtained $55,6 \%$ of referrals and $35,3 \%$ of spontaneous demand, data similar to those of this study, with $54,4 \%$ and $35,8 \%$, respectively.

Between 2001 and 2007, it was observed that the coefficient of detection of new cases of leprosy in Brazil presented values related to males higher than those referring to females. ${ }^{9}$ In this period, the state of Paraná presented 773 new cases of male sex $(56,3 \%)$ and 601 female cases $(43,7 \%)$, similar to the prevalence observed between 2007 and 2015 , with male involvement ( 6.444 cases, $58,3 \%$ ) was higher than the female (4.612 cases, $41,7 \%)$. Figure 1 shows the annual incidence of reported cases between genders. The highest incidence of reported female cases occurred only in 2009, different from the other years in which there was a prevalence of reports of male cases, and a peak incidence of these cases in 2015. According to Moreira et al. ${ }^{15}$ in 2014, the construction of masculinity directly influences vulnerability to more serious and chronic diseases, and, above all, to earlier death. ${ }^{15}$ In this way, more men die than women during the evolutionary cycle of life, and many of these deaths could be avoided if there was no male resistance in the search for health services, especially primary care. On the other hand, there is access of men to health services through tertiary care, when there is already a clinical situation of morbidity, often chronicled and that demands high social costs for men and economic cost for the State. The male age range of hospitalizations in SUS (Health Unic System in Brazil) is between 20 and 29 years, but most of these hospitalizations are related to external causes. ${ }^{15,16}$ Gomes et al. ${ }^{16}$ in 2007 concluded that the demand for health services is closely related to the roles to be played in order to establish the identity of being male.

Source:The Author.

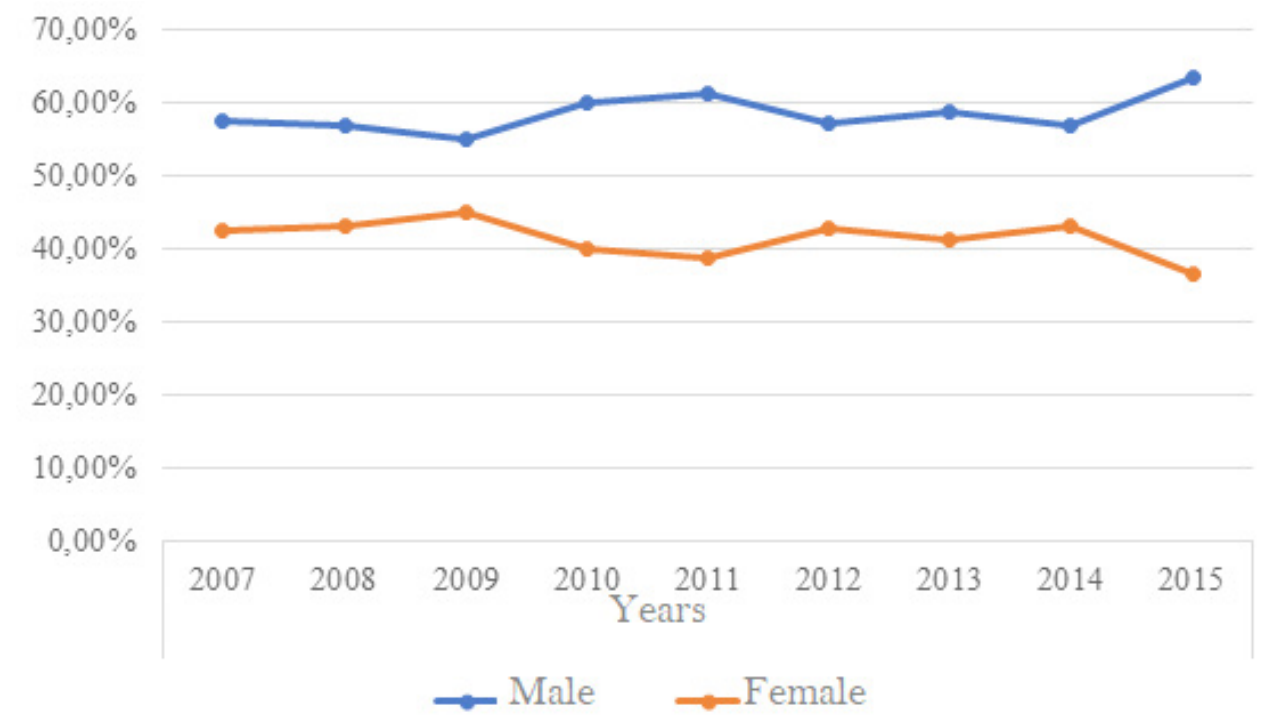

Figure I Distribution of Hanseníase cases notified in the state of paraná per year (2007-20I5) as SEEN (N= II.056). 
Many men associate the idea of self-care with the feminine sphere, justified by the socialization that women receive to reproduce and to be responsible for maintaining social relations and providing services to others. On the other hand, being a man would be associated with invulnerability, strength and virility, characteristics incompatible with weakness, fear, anxiety and insecurity, represented by the demand for health services. ${ }^{15,16}$ In addition, there are allegations that the hours of operation of the health services do not meet the demands of men as they coincide with the workload as well as the precariousness of the work, which is another reason not to seek help. There is also the fact that there is a strong association in being a provider and being a man in the social imaginary, reinforcing the roles historically attributed to men that they need to guarantee family subsistence. In 2008, MOH implemented the National Policy for Integral Attention to Human Health to promote health and prevent diseases among this population, considering that the socio-cultural construction of the human being has produced behaviors and attitudes that negatively influence the determinants of the health process and to include men in primary health care is a challenge to public policies, but it must be addressed. ${ }^{9,15}$

Regarding ethnicity, there was a prevalence of the disease in white individuals (7.957 cases, $72,1 \%)$. This finding was attributed to the racial characteristics of the southern region of the country, and similar to that of Batista et al. ${ }^{17}$ in 2009 , whose prevalence was of $53,4 \%$ of the analyzed population. ${ }^{17}$ According to Pereira et al. ${ }^{18}$ adults with a mean age of 50 years (median 51,1, minimum age 2,2 years and maximum of 98,5 years, with standard deviation 16,1 ) predominated. Subjects with male gender and incomplete elementary school were the most affected (3.995 cases, 63,5\%), a finding similar to that observed by Brito et al. ${ }^{19}$ in their study of the Brazilian northeast. Regarding schooling, the majority of reported female cases also had incomplete elementary education ( 2.647 cases, $58,9 \%$ ). The Ministry of Health in 2008 presented national data (2001-2007) with percentages different from those observed in this study, because it evaluated the educational level only in relation to new cases and the age group of 15 years or more. ${ }^{9}$ Data regarding the epidemiological profile of the population with leprosy in Paraná are related to all cases, including the old ones, and to all age groups. Both in the MOH study in 2008 and in this study there was a prevalence of incomplete elementary education among those analyzed.

Source:The Author
Between 2007 and 2015, patients reported in other states were also treated in Paraná. In total, 15 male cases $(0,25 \%)$ and 4 female cases $(0,07 \%)$ were reported in other locations. According to Fiocruz, the states of Mato Grosso, Pará, Maranhão, Tocantins, Rondônia and Goiás are the areas with the highest risk of transmission of leprosy, concentrating more than $80 \%$ of the total cases diagnosed. ${ }^{20}$ On the other hand, the states of Rio Grande do Sul and Santa Catarina were able to eliminate leprosy, while the states of São Paulo, Rio Grande do Norte, and the Federal District were on their way to total elimination. ${ }^{9,21}$ From 2001 to 2007, the Ministry of Health revealed that the majority of new cases under the age of 15 were in Tocantins $(23,68 \%)$. Paraná, on the other hand, was placed in the group with the lowest coefficients of detection of new cases per 100.000 inhabitants, with only $0,8 \%$ of cases at this age. ${ }^{9}$ It can be observed that in the period from 2007 to 2015 only 1 case notified in Tocantins was rescued and treated in Paraná. It was not possible to identify the age at diagnosis. Based on these data, it was possible to evaluate health macro-regions that received these patients in the state of Paraná. The macroregions with the highest population of cases were in descending order: Metropolitan Region of Curitiba (1.367 cases), followed by Londrina (937 cases) and Foz do Iguaçu (862 cases). On the other hand, the macro-region of health that presented smaller population of cases in the period was União da Vitoria with only 121 cases.

There were 10,986 cases reported in the state of Paraná. Of these, 4.593 were female and 6.393 were male. The macroregion with the highest incidence of reported female cases was Londrina, with 415 cases $(9 \%$ of the total), while the macroregion of the Metropolitan Region of Curitiba had a higher incidence of reported cases of males, with 900 cases $(14,1 \%$ of the total). The prevalence of patients classified as Virchowian (4.186 cases, 38,3\%) and Dimorph (3.424 cases, $31,3 \%$ ) differed according to the data found in the study by Pereira and collaborators ${ }^{18}$ in Anápolis (GO), which revealed greater prevalence of the Dimorph form $(69,91 \%)$ followed by the Virchowian form $(18,29 \%)$. Figure 2 shows the distribution of the clinical forms between genders, with predominance of virchowian form among men $(47,3 \%)$ followed by the dimorphic form $(32 \%)$, while with women the opposite occurs, with predominance of dimorphic form $(33,1 \%)$ followed by the Virchowian form (29\%). In a retrospective study performed by Melão et al. ${ }^{6}$ in Santa Catarina, a predominance of $39,1 \%$ of the cases of the virchowian form was found in males, and in females, $28,5 \%$, both in the indeterminate and dimorphic forms.

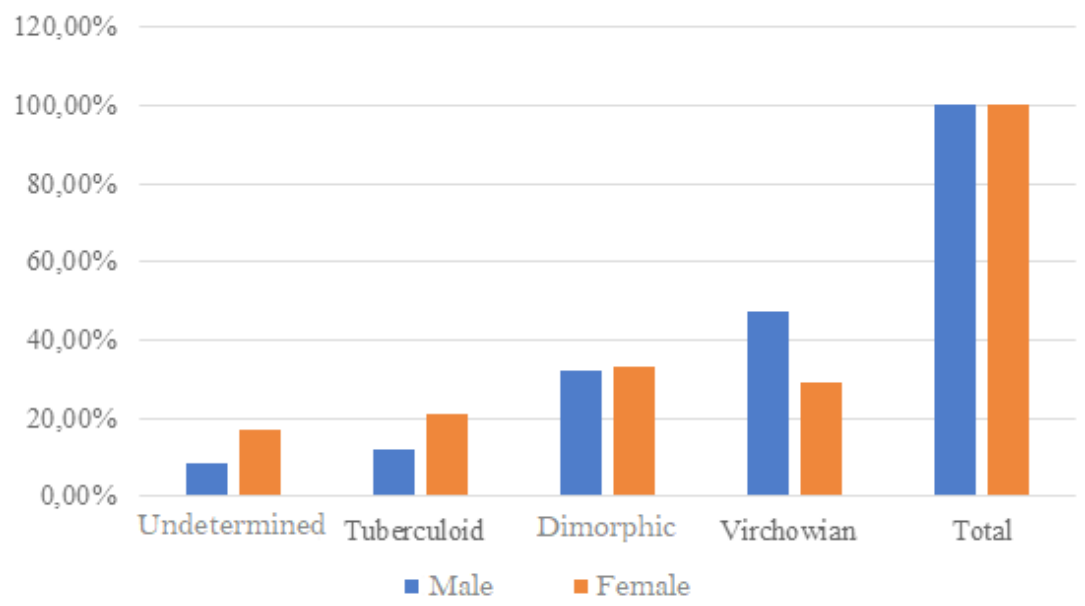

Figure 2 Percentage of the clinical form present between genders $(\mathrm{N}=1 \mathrm{I} .056)$. 
It was also possible to determine the operational classification among the 11.056 cases, with the multibacillary class identified in $75,2 \%$ of the patients (8.319) and the paucibacillary class in $24,8 \%$ (2.737), which corroborates the results found in the retrospective study of 1998 to 2005 in the city of Prudentópolis-PR, where the multibacillary class presented predominance of $63 \%$ of the cases. ${ }^{22}$ After diagnosis, the treatment was performed according to the operational classification of the disease. The treatment regimen with polychemotherapy ${ }^{13,23,24}$ (treatment with rifampicin, dapsone and clofazimine) was separated between paucibacillary patients (who received 6 doses) totaling 24\%, and among multibacillary patients (who received 12 doses in total), accounting for $72 \%$. Other substitution schemes were also used for $4 \%$ of patients. In total, 10.987 patients received drug treatment. Regarding the type of discharge obtained, 9.166 patients were cured $(82,9 \%)$-Table 2 , a fact comparable to that found by Miranzi et al in 2010, where 83,9\% obtained the same outcome $^{14}$. Regarding the physical incapacity at discharge, $68,42 \%$ of the patients with an indeterminate form improved, as well as $67,01 \%$ of the tuberculoid form, $62,05 \%$ of the dimorphic and $65,51 \%$ of the virchowian. However, in general, there was a predominance of physical disability in the dimorphic form (37.65\%), similar to that of Júnior et al. ${ }^{27}$ in which the dimorphic and virchowian clinical forms had a high rate of residual disability in the studied group. ${ }^{25-27}$

Table 2 Type of outpatient discharge of the patient related to the clinical form $(\mathrm{N}=\mid \mathrm{I} .056)$

\begin{tabular}{lllll}
\hline Treatment outcome & Clinical form & & & \\
\hline & Undetermined & Tuberculoid & Dimorphic & Virchowian \\
\hline Cure & $1.15 \mathrm{I}$ & $1.52 \mathrm{I}$ & 2.962 & 3.532 \\
& $90,8 \%$ & $92,9 \%$ & $89,7 \%$ & $88,8 \%$ \\
Transfer & 41 & 39 & 137 & 177 \\
& $3,2 \%$ & $2,4 \%$ & $4,1 \%$ & $4,4 \%$ \\
Death & 10 & 15 & 80 & 151 \\
& $0,8 \%$ & $0,9 \%$ & $2,4 \%$ & $3,8 \%$ \\
Abandonment & 24 & 28 & 95 & 90 \\
\multirow{2}{*}{ Diagnostic error } & $1,9 \%$ & $1,7 \%$ & $2,9 \%$ & $2,3 \%$ \\
& 42 & 34 & 29 & 29 \\
Total & $3,3 \%$ & $2,1 \%$ & $0,9 \%$ & $0,7 \%$ \\
\hline
\end{tabular}

Source:The Author

\section{Conclusion}

The data suggest the occurrence of annual changes in the number of reported cases of leprosy in the state of Paraná. The predominance of the involvement of adult males of reproductive age and of multibacillary forms, especially of the most severe, systemic and debilitating Virchowian form, shows that the importance of investing in the structuring of the health information system in order to better evaluate epidemiology, for early detection, treatment, prevention and rehabilitation of cases, and raising awareness of the severity of leprosy is necessary to close and interrupt the development of the disease.

\section{Acknowledgments}

Jaqueline Final, Ândrea Mattos and Jelly Christine Rigoni (data providers of the State Coordination of the Leprosy Control Program of the Health Department of the State of Paraná, SESA-PR); and our statistic Márcia Olandoski.

\section{Funding details}

The study did not receive funding.

\section{Conflicts of interest}

The author declares that there are no conflict of interest.

\section{References}

1. IBGE. Sistema de Informações de Agravos de Notificação - SINAN. Instituto Brasileiro de Geografia e Estatística. Brasília. 2016.

2. Cunha AZS. Leprosy: evolution aspects of its diagnosis, treatment and control. Ciência \& Saúde Coletiva. 2002;7(2):235-242.

3. Araújo MG. Hanseníase no Brasil. Rev Soc Bras Med Trop. 2003;36(3):373-382.

4. Ministério da Saúde. Secretaria de Vigilância em Saúde. Departamento de Vigilância das Doenças Transmissíveis. Diretrizes para vigilância, atenção e eliminação da hanseníase como problema de saúde pública: Manual técnico operacional. Brasília (DF): Ministério da Saúde, 2016.

5. Lastória JC, Abreu MAMM. Hanseníase: diagnóstico e tratamento. Diagn Tratamento. 2012;17(4):173-179.

6. Melão S, Blanco LFO, Mounzer N, et al. Perfil Epidemiológico dos Pacientes com Hanseníase no Extremo Sul de Santa Catarina, no Período de 2001 a 2007. Rev da Soc Bras de Med Trop. 2011;44(1):79-84.

7. Souza CS. Hanseníase: formas clínicas e diagnóstico diferencial. Rev Facul Med Ribeirão Preto. 1997;30:325-334.

8. World Health Organization, Regional office for south-east Asia. Global Leprosy Estrategy - Acceleratig towards a leprosy-free world. Genebra. 2015 .

9. Ministério da Saúde. Vigilância em saúde: situação epidemiológica do Brasil 2008. Brasilía, 2008. p. 1-12.

10. Rede Interagencial de Informações para Saúde. Taxa de prevalência de hanseníase. Brasília. 2007.

11. Ministério da Saúde; Secretaria de Vigilância em Saúde. Boletim Epidemiológico. Brasília. 2013;44(11).

12. Lima LS, Jadão FRS, Fonseca RNM, et al. Caracterização clínicaepidemiológica dos pacientes diagnosticados com hanseníase no município de Caxias, MA. Rev Bras Clin Med. 2009;7:74-83. 
13. Ministério da Saúde, Secretaria de Vigilância em Saúde, Departamento de Vigilância das Doenças Transmissíveis. Plano Integrado de Ações Estratégicas de eliminação da hanseníase, filariose, esquistossomose e oncocercose como problema de saúde pública, tracoma como causa de cegueira e controle das geohelmintíases. Plano de ação 2011-2015. Brasília - DF. 2012. p. 1-104

14. Miranzi SSC, Pereira LHM, Nunes AA. Perfil epidemiológico da hanseníase em um município brasileiro, no período de 2000 a 2006. Rev da Soc Bras de Med Trop jan-fev. 2010;43(1):62-67.

15. Moreira RLSF, Fontes WD, Barbosa TM. Dificuldades de inserção do homem na atenção básica a saúde: a fala dos enfermeiros. Esc Anna Nery. 2014;18(4):615-621.

16. Gomes R, Nascimento EF, Araújo FC. Por que os homens buscam menos os serviços de saúde do que as mulheres? As explicações de homens com baixa escolaridade e homens com ensino superior. Cad Saúde Pública. 2007;23(3):545-574

17. Batista ES, Campos RX, Queiroz RCG, et al. Perfil sócio-demográfico e clínico-epidemiológico dos pacientes diagnosticados com hanseníase em Campos dos Goytacazes, RJ. Rev Bras Clin Med mar-abr. 2011;9(2):101106.

18. Pereira DL, Brito LM, Nascimento AH, et al. Estudo da prevalência das formas clínicas da hanseníase na cidade de Anápolis-GO. Ensaios e Ciência: Ciências Biológicas, Agrárias e da Saúde. 2012;161(,):55-67.

19. Brito KKG, Araújo DAL, Uchôa MN, et al. Epidemiologia da hanseníase em um estado do nordeste brasileiro. Rev enferm UFPE. 2014;8(8):26862693.
20. Fundação Oswaldo Cruz. Hanseníase: Brasil é o único país que não conseguiu eliminar a sua propagação. Rio de Janeiro, 2016.

21. Eidt LM. Breve história da hanseníase: sua expansão do mundo para as Américas, o Brasil e o Rio Grande do Sul e sua trajetória na saúde pública brasileira. Saúde e Sociedade maio-ago. 2004;13(2):76-88.

22. Sanches LAT, Pittner E, Sanches HF, et al. Detecção de casos novos de hanseníase no município de Prudentópolis, P R: uma análise de 1998 a 2005. Rev da Soc Bras de Med Trop set-out. 2007;40(5):541-545.

23. Sociedade Brasileira de Dermatologia. Hanseníase. São Paulo, 2012.

24. Ministério da Saúde, Secretaria de Vigilância em Saúde, Departamento de Vigilância Epidemiológica. Guia de procedimentos técnicos Baciloscopia em Hanseníase. Brasilía, 2014. p. 1-54.

25. Martins BDL, Torres FN, Oliveira MLWDR. Impacto na qualidade de vida em pacientes com hanseníase: correlação do Dermatology Life Quality Index com diversas variáveis relacionadas à doença. An Bras Dermatol. 2008;83(1):39-43.

26. Rocha AKAA, Júnior EDS, Novaes MM, Franco CIF. Análise da independência funcional em pacientes com neuropatia hanseniana assistidos pelo centro de referência em hanseníase da cidade de campina grande - Paraíba. Bios Rev Saúde e Biol. 2014;9(3):8-16.

27. Júnior AFR, Vieira MA, Caldeira AP. Perfil epidemiológico da hanseníase em uma cidade endêmica no Norte de Minas Gerais. Rev Bras Clin Med jul-ago. 2012;10(4):272-277. 